\title{
Whither the etiopathogenesis (and scoliogeny) of adolescent idiopathic scoliosis? Incorporating presentations on scoliogeny at the 2012 IRSSD and SRS meetings
}

R Geoffrey Burwell ${ }^{1 *}$, Peter H Dangerfield ${ }^{2,3,4}$, Alan Moulton ${ }^{5}$, Theodoros B Grivas ${ }^{6}$ and Jack CY Cheng ${ }^{7}$

\begin{abstract}
This paper aims to integrate into current understanding of AIS causation, etiopathogenetic information presented at two Meetings during 2012 namely, the International Research Society of Spinal Deformities (IRSSD) and the Scoliosis Research Society (SRS). The ultimate hope is to prevent the occurrence or progression of the spinal deformity of AIS with non-invasive treatment, possibly medical. This might be attained by personalised polymechanistic preventive therapy targeting the appropriate etiology and/or etiopathogenetic pathways, to avoid fusion and maintain spinal mobility. Although considerable progress had been made in the past two decades in understanding the etiopathogenesis of adolescent idiopathic scoliosis (AIS), it still lacks an agreed theory of etiopathogenesis. One problem may be that AIS results not from one cause, but several that interact with various genetic predisposing factors. There is a view there are two other pathogenic processes for idiopathic scoliosis namely, initiating (or inducing), and those that cause curve progression. Twin studies and observations of family aggregation have revealed significant genetic contributions to idiopathic scoliosis, that place AIS among other common disease or complex traits with a high heritability interpreted by the genetic variant hypothesis of disease. We summarize etiopathogenetic knowledge of AIS as theories of pathogenesis including recent multiple concepts, and blood tests for AIS based on predictive biomarkers and genetic variants that signify disease risk. There is increasing evidence for the possibility of an underlying neurological disorder for AIS, research which holds promise. Like brain research, most AIS workers focus on their own corner and there is a need for greater integration of research effort. Epigenetics, a relatively recent field, evaluates factors concerned with gene expression in relation to environment, disease, normal development and aging, with a complex regulation across the genome during the first decade of life. Research on the role of environmental factors, epigenetics and chronic non-communicable diseases (NCDs) including adiposity, after a slow start, has exploded in the last decade. Not so for AIS research and the environment where, except for monozygotic twin studies, there are only sporadic reports to suggest that environmental factors are at work in etiology. Here, we examine epigenetic concepts as they may relate to human development, normal life history phases and AIS pathogenesis. Although AIS is not regarded as an NCD, like them, it is associated with whole organism metabolic phenomena, including lower body mass index, lower circulating leptin levels and other systemic disorders. Some epigenetic research applied to Silver-Russell syndrome and adiposity is examined, from which suggestions are made for consideration of AIS epigenetic research, cross-sectional and longitudinal. The word scoliogeny is suggested to include etiology, pathogenesis and pathomechanism.
\end{abstract}

Keywords: Scoliosis, Etiology, Pathogenesis, Scoliogeny, Epigenetics

\footnotetext{
* Correspondence: gburwell@tiscali.co.uk

${ }^{1}$ Centre for Spinal Studies and Surgery, Nottingham University Hospitals

Trust, Queen's Medical Centre Campus, Derby Road, Nottingham NG7 2UH,

UK

Full list of author information is available at the end of the article
} 


\section{Review}

This paper aims to integrate into current thinking about AIS causation, etiopathogenetic information presented at two Meetings during 2012 namely, the International Research Society of Spinal Deformities (IRSSD) and the Scoliosis Research Society (SRS). This is done by arranging extracts of selected presentations as paragraphs (with bold italicised headings) into the structure of an invited review article published at that IRSSD Meeting beginning with the Abstract [1]. These placements reveal where progress is being made and suggest fields where the focus is becoming clearer, needs enlarging, or is neglected. There is a lack of such collated updated preliminary etiopathogenetic researches in the literature. No attempt is made here to provide level of evidence for the selected presentations - most of which are not full papers. Nor are the findings interpreted with respect to theories of curve initiation, progression, or the consequence of having AIS, other than that provided by their authors. Readers are invited to apportion significance to those researches that interest them.

\section{Terminology}

The word etiology strictly means the factor(s) causing the AIS, pathogenesis mode of origin of the morbid process, and pathomechanism sequence of events in the evolution of its structural and functional changes that result from the pathological process [2]. The word etiopathogenesis is used to embrace etiology and pathogenesis. We suggest the word scoliogeny as the collective noun to include etiology, pathogenesis and pathomechanism.

\section{Introduction}

Research into the causation of adolescent idiopathic scoliosis (AIS) draws heavily from mechanical and biological disciples, but still lacks an agreed theory of etiopathogenesis [3-10]. Genetic factors are believed to play an important role in the etiology of AIS with considerable heterogeneity $[5,6]$. The research problem is complicated by the suspicion that AIS may result not from one cause, but several that interact $[3,9]$. Genetic, and now genomic, research on AIS have not yet provided the therapeutically-required etiologic understanding. In other diseases and particularly diseases of developmental origin [11] and late-onset chronic noncommunicable diseases (NCDs) [12], research on the role of environmental factors and epigenetics after a slow start has exploded in the last decade [12-17]. Not so for AIS research and the environment where, except for monozygotic twin studies, there are only sporadic reports suggesting that environmental factors are at work in etiology [18]. Epigenetics, a relatively recent field, evaluates factors concerned with gene expression in relation to environment, disease, normal development and aging, with a complex regulation across the genome during the first decade of life. Elsewhere we commented on etiopathogenetic concepts as they may relate to normal spine development and AIS pathogenesis [18]. Here we consider:

(1) some theories of pathogenesis including recent multiple concepts;

(2) blood tests for AIS based on predictive biomarkers and genetic variants that signify disease risk;

(3) epigenetic concepts as they may relate to human development and life history phases;

(4) AIS linked to the aging process as a noncommunicable disease (NCD);

(5) findings from epigenetic methods applied to the Silver-Russell syndrome and adiposity; and

(6) suggestions for applying epigenetic methods to AIS etiopathogenesis in cross-sectional and longitudinal studies.

\section{Etiopathogenesis 2011}

In a review of Top Theories of AIS Wang et al. [5] concluded:

- considerable progress had been made in the past two decades in understanding the etiopathogenesis of AIS;

- current knowledge is still fragmented;

- we are still far from understanding fully the different etiopathogenetic pathways and mechanisms for example -

- the general skeletal and relative anterior spinal overgrowth (RASO) of AIS girls have not been related securely to endocrinology;

- the abnormal extra-spinal skeletal length asymmetries of AIS girls are of unknown pathogenetic significance;

- current treatment at best is treating the morphologic and functional sequelae of AIS and not the cause of the disease; and

- whatever hypothesis or theory, several fundamental questions and facts of AIS need to be properly addressed and explained with 11 items listed.

\section{Pathogenesis - theories, hypotheses and concepts 2012}

Several theories, hypotheses and concepts for AIS pathogenesis more recently implicating AIS as a systemic and/ or multifactorial disorder, are providing hypotheses to test. [3-5,7]. These include:

- Relative anterior spinal overgrowth (RASO) [19]. 
Sagittal spinal profile in fathers and mothers of AIS girls. In Utrecht, The Netherlands, Janssen et al. [20,21] tested the hypothesis that the familial trend of AIS is explained by the inheritance of the sagittal spinal profile, making the spine less resistant to rotatory forces. Using free-standing lateral spinal radiographs of 51 parent couples of girls with severe progressive AIS and 102 age-matched controls, they found that the fathers, but not the mothers had significantly flatter sagittal spinal profiles.

Forceful restoration of the thoracolumbar lordosis to correct double major AIS. In Enschede, The Netherlands, Van Loon [22] reviewed factors in healthy children that can deform their spines.

The use of growth in thoracolumbar lordotic intervention for the brace treatment of AIS. In Enschede, The Netherlands van Loon et al. [23] evaluated old and new concepts on the pathogenesis of AIS with respect to thoracolumbar lordotic intervention for brace treatment.

Pelvic incidence and lordosis (anterior pelvic tilt). In Utrecht, The Netherlands, Janssen et al. [24] defined pelvic lordosis as the angle between the axis of the ischium and a line connecting the midpoint of the sacral endplate to the hip axis. Pelvic lordosis correlated strongly with pelvic incidence. Its role in spinal pathology deserves further investigation.

- Asynchronous spinal neuro-osseous growth $[25,26]$.

Typical and atypical AIS. In St Petersburg, Russia, Dudin and Pinchuk [27] presented a theory of AIS pathogenesis. Two forms of AIS are identified: typical AIS with convex-side axial vertebral rotation; and atypical scoliosis with concave-side axial vertebral rotation. The components of the theory are:

1) Growth under nervous and endocrine system control in pre-pubertal and pubertal periods differing in girls and boys, with "personal" programs in spinal cord and its bone-ligament-muscular sheath.

2) Non-conjugacy of growth (growth conflict) between spinal cord and its bone sheath - termed by others asynchronous, or uncoupled, neuro-osseous growth. This non-conjugacy of growth with -

a) excess length of vertebral column leads to convex-side vertebral rotation (typical AIS), and

b) decreased length of vertebral column leads to concave-side vertebral rotation (atypical AIS).

3) Formation of a scoliosis curve(s) involving HueterVolkmann effect and a vicious circle (Stokes),

- Thoracospinal concept [28].

- Dorsal shear forces and axial rotation instability [29].
Pre-existing axial rotation of the normal spine. In an Invited Lecture, Castelein [30] in Utrecht, The Netherlands, reviewed their analysis of the rotational patterns of the normal growing and adult spine in relation to closure of the neurocentral junctions, organ anatomy, and the convexity of the curve in idiopathic scoliosis.

Neurocentral junction (NCJ) in the normal growing spine. In Utrecht, The Netherlands, Schlosser et al. [31] evaluated the closure pattern and symmetry of left and right NCJs in the normal human growing spine in relation to pre-existing axial spinal rotation and the convexity of the curve in AIS.

- Flexural-torsional buckling from flexibility anisotropy [32].

- Biomechanical spinal growth modulation [33].

Effects of carrying weight on posture. In Middlesborough, UK, Bettany-Saltikov and Cole [34] evaluated the effects of carrying weights (front packs, shoulder bags and hand held bags, each about $15 \%$ of body weight) on back shape and posture using an ISIS2 scanner on 25 university students. The shoulder and hand held bags produced postural deviations in all planes; these may cause stress and strain on the spine and lead to scoliosis curve progression.

Lumbo-sacral-joint efforts during gait and HueterVollkmann effect. In Montreal, Canada, Brussels, and Louvain, Belgium, Raison et al. [35] studied adolescents with left lumbar and thoracolumbar AIS and controls using an acquisition system involving body joint motion via optokinetic sensors and ground reaction forces via a treadmill fitted with force sensors. At L5-S1 subjects with severe AIS had higher medio-lateral forces than the controls which could lead to asymmetrical vertebral growth modulation and curve progression (Hueter-Volkmann effect).

Growth-plate mechanobiology. In Montreal, Canada, Menard et al. [36] studying rat caudal vertebrae found dynamic loadings modulated growth with less damage to growth plates than static loading.

Effect of torque on growth in caudal vertebrae. In Milwaukee, USA, Rizza et al. [37] using the rat tail, applied torsional loads to vertebrae that led to curvature in growth-plate morphology and remarkably increased growth-plate thickness.

Osteoblasts, biomechanical stress and oestrogens. In Montreal, Canada, Moldovan et al. [38] in AIS subjects demonstrated that biomechanical stress and estradiol are involved in the expression of certain genes. Cultured osteoblasts subjected to biomechanical stress showed increased levels of NO, COX-2, OPN, and ATP levels in both control cells and AIS cells with significantly higher levels of NO and COX-2 in AIS cells.

- Biomechanical theory [39]. 
Causative role of gait and standing at ease on right leg. In Lublin, Poland, Karski [40] outlined his theory that idiopathic scoliosis is connected with gait and persistent standing at ease on the right leg. Scoliosis, results from asymmetry of function proving the possibility of causative prophylaxis.

- Intervertebral disc disorder [41-47].

- Deforming three joint complex hypothesis [48].

- Motor control disorder [49-51].

Hand grip strength. In Hong Kong, China, Yu et al. [52] fond that hand grip strength was lower than controls suggesting muscle dysfunction in AIS.

- Sensorimotor integration disorder \& dystonia [51,53].

- Sensory integration disorder [54].

- Vestibular disorder [55].

Semicircular canals. In Hong Kong, China, Chu et al. [56] used MRI to evaluate the morphology of semicircular canals (SSCs) in subjects with right thoracic AIS and controls. Significant differences in the shape of left, but not right, SSCs were found between AIS and controls. It was suggested that these morphological changes are likely to be related to subclinical postural, vestibular and proprioceptive dysfunctions in AIS subjects.

- Body spatial orientation disorder [57].

- Neurodevelopmental disorder [58].

- Systemic and metabolic disorders involving -

O Platelet calmodulin $[59,60]$.

○ Melatonin [61-64].

Melatonin receptors. In Hong Kong, China Yim et al. [65] extended their previous research which showed that melatonin receptor 1B (MTNR1B) was not detected in osteoblasts of some AIS girls. In 41 AIS girls, while MTNT1A and MTNR1B were found in all, that of MTN1RB was lower, suggesting a quantitative rather than a qualitative difference linked to the pathogenesis of AIS.

O Melatonin-signalling defect (MSD) [66,67].

O Osteopontin (OPN) and soluble CD44 (sCD44). Azeddine et al. [68] and Moreau et al. [69] reported mean plasma OPN levels to be increased in:

- patients with idiopathic scoliosis, correlating significantly with curve severity, and

- "an asymptomatic at-risk group" (offspring born from at least one scoliotic parent); this finding, if confirmed, suggests predictive biomarkers and possibly a prodromal stage with the prospect of intervention early in deformity evolution.

In contrast, mean plasma levels of sCD44 were significantly lower in patients with Cobb angles of 45 degrees or more. Drawing on evidence from mouse models, it was concluded that OPN is essential to induce scoliosis formation and curve progression through interactions with CD44 receptors, "....thus offering a first molecular concept to explain the pathomechanism leading to the asymmetrical growth of the spine in idiopathic scoliosis." [69].

Moreau and colleagues report that blood tests could be useful markers for the diagnosis of idiopathic scoliosis and the prognosis of curve progression: a functional scoliosis test [66-70], further refined recently using a more accurate technology called cellular dielectric spectroscopy [71]; and a biochemical scoliosis test using raised plasma OPN and lower sCD44 values. Moreau [72] states that OPN and sCD44 are not disease-specific but when observations of both are combined they become highly specific for idiopathic scoliosis. By binding free OPN, sCD44 can prevent OPN from triggering scoliosis or curve progression. Moreau considers that environmental factors could potentially affect the circulating levels of OPN in humans. With colleagues he is conducting tests to identify potentially useful therapeutic agents [72].

High osteopontin (OPN).l levels and bone mineral density. In China and Montreal, Sun et al. [73] in 45 AIS girls demonstrated that low cortical bone mineral density in the distal radius is significantly associated with high OPN levels. It is stated that high osteopontin levels in plasma may reflect underlying abnormalities of bone mineralization in AIS subjects.

PTPX and HSJ family members as disease-modifying factors in AIS. In Montreal, Canada, Elbakry et al. [74] stated that their previous research had found that AIS patients have a Gi protein signalling defect and high levels of circulating osteopontin (OPN). Here, on AIS and control osteoblasts, they investigated Protein Tyrosine Phosphatase $\mathrm{x}$ (PTPx) and HSJ-1 related family members to determine their potential contribution to OPN receptor activity. Bipedal PTPx knock-out mice were also evaluated. It was found that PTPx and HSJ-1 messenger RNA and protein levels were decreased in all 34 AIS patients compared with 17 controls. They concluded that PTPx and some of the HSJ family members have potential roles in AIS etiopathogenesis as disease-modifying factors exacerbating scoliosis development triggered by OPN.

O Oestrogens $[75,76]$.

Oestrogen receptor 2 (ESR2) expression in back muscles. In Poznan, Poland, Rusin et al. [77] reported asymmetric ESR2 in deep paravertebral muscles more 
on the convexity than the concavity. With ESR2 convex/ concave ratios of 1 or more, the ratio correlated with Cobb angle.

$$
\text { O Leptin }[7,76,78,79] \text { (see 9.1.3) }
$$

Leptin and bone mineral density. In Hong Kong, China, Tam et al. [80,81] in AIS and control girls, evaluated correlations between each of leptin and soluble leptin receptor (sOB-R) and volumetric bone mineral densities (vBMDs) of various bone compartments scanned at the distal radius using high resolution peripheral quantitative computed tomography (HR- pQCT). They stated that serum total leptin has an anabolic effect on BMD and suggested that AIS girls have an abnormal bone metabolic response to serum leptin. It is unclear whether this represents signalling dysregulation, or abnormal leptin bioavailability between bone compartments. (compact and trabecular).

Leptin and cellular dysfunction. In Hong Kong, China, Tam et al. [82] reported that AIS girls have lower BMI, free leptin index (leptin/sOB-R), and higher sO-BR than controls. sOB-R expression correlated abnormally with each of fat content, BMI and leptin compared with controls. The authors speculate firstly, that AIS girls have cellular dysfunction that results in abnormal sOB-R expression which in turn may cause abnormal leptin bioavailability; and secondly, that sOB-R may predict curve progression.

High central leptin activity in a mouse scoliosis model. In Nanjing, China, Wu et al. [83] reported results which indicated that high central leptin activity might increase the risk of developing a scoliosis in bipedal mice and contribute to scoliosis progression.

Serum ghrelin levels. In France, de Gouzy et al. [84] found higher average levels of total serum ghrelin in AIS subjects compared with controls after adjusting for BMI. They suggested that ghrelin participates in the pathophysiology of AIS possibly involving ghrelin-like cell resistance to melatonin hormone.

Neurohormonal regulation. In St Petersburg, Russia, Khaymina et al. [85] evaluated blood serum from 120 children age 8-15 years with AIS, Biotesting was performed on male Wistar rats with thoracic spinal cord transection. After 30 minutes and injecting the serum into the lumbar spinal canal, EMG activity of both hind limbs was recorded as a coefficient of movement disorder (CMD). The CMDs revealed scoliosis type by progression that are claimed to provide new opportunities for understanding the pathogenesis and methods of treatment for AIS.

- Osteopenia [86-88].

Bone mineralization. In China, Sun et al. [89] evaluated cancellous bone from AIS and normal age-matched healthy subjects. Bone mineral density (quantitative microCT) and undecalcified histomorphometry were studied. The findings showed that AIS girls had lower bone mineralization than normals. It is suggested that an abnormality of bone matrix may play an important role in the etiopathogenesis of AIS.

Bone quality. In Hong Kong, Yu et al. [90,91] reported that bone quality in osteopenic AIS girls was uniquely different from that of osteopenic non-AIS controls. Trabecular compartment alterations with osteopenia were only present in AIS girls, a finding that needs etiopathogenic assessment.

- Developmental instability \& symmetry control dysfunction [92,93].

- Intrinsic growth plate asymmetry hypothesis [94,95].

- Multiple pathogenetic processes.

O Double neuro-osseous theory $[7,96]$.

O Three components [10].

O Four components $[58,97,98]$.

Is AIS under 20-30 degrees a chaotic dynamical system? In Lyon and Toulon, France, de Mauroy and Ginoux [99] outlined the relation of AIS to chaos.

\section{Some comments on theories, hypotheses and concepts 2012}

Attempts at integration of theories

None of the above theories entirely explain the pathogenesis of AIS $[3-5,7,10,68]$. In recent surveys of these theories for AIS $[3-5,7,10,98]$, integration is attempted by involving interacting pathomechanisms. In addition to predisposing factors $[3,6]$, there is a view that there are two other pathogenic processes for idiopathic scoliosis namely, initiating (or inducing), and those that cause curve progression $[3,100]$. There is evidence that curve progression, which increases during the curve acceleration phase [101], increases through disc wedging during the rapid growth spurt with progressive vertebral wedging occurring later $[45,46]$; and that in scoliosis the simultaneous occurrence of vertebral displacement in 3$D$, rather than a specific single disturbance of any one of the three planes, triggers development of the deformity [102].

Skeletal-size-for-age in single thoracic and single lumbar AIS. In Hong Kong and Nanjing, China, Liu et al. [103] compared anthropometric parameters of girls with single thoracic and single lumbar AIS, each against 3914 healthy girls. Compared with healthy girls, thoracic and lumbar AIS, girls had higher corrected standing and sitting height, arm span and leg length. Compared between thoracic and lumbar AIS, corrected standing and 
sitting height were not significantly different. Thoracic AIS girls were leaner than healthy girls.

Abnormal skeletal growth patterns. In Hong Kong, China, Yim et al. [104] in girls age 12-16 years evaluated growth of two AIS groups (severe and moderate scoliosis) and control girls. In a cross-sectional study, severe AIS at age 12 started with a shorter arm span than moderate AIS and controls, but overtook at 14-16 years. In the longitudinal study from $12-16$ years, moderate AIS had longer arm span than controls with similar growth rate. Severe AIS had a higher growth rate than moderate AIS. It is concluded that the growth spurt during puberty is a key factor associated with pathogenesis and curve progression in AIS. It is suggested that arm span growth could be used to predict severe scoliosis in AIS.

Height velocity curves. In Tokyo, Japan, Chazono et al. [105] calculated peak height velocity (PHV) on 20 skeletally immature girls with idiopathic scoliosis with a follow-up period of 5.2 years. The findings were compared with standard data from unaffected girls. The findings show that while the PHV was higher and the growth period shorter in IS girls than in unaffected girls. It was suggested that curve progression is associated with the magnitude of PHV. and duration of the growth process.

\section{RASO phenomenon and asynchronous spinal neuro- osseous growth concept}

Relative anterior spinal overgrowth (RASO) is established as a sagittal plane phenomenon associated with scoliosis. Its etiologic mechanisms are unknown but curve progression is thought to involve the Hueter-Volkmann effect [33]. Some workers adduce evidence that RASO results from a spinal neuro-osseous growth disorder - variously termed vertebra-neural (Roth, van Loon), uncoupled (Porter), and asynchronous [25] - of unknown etiology. Without riders these sagittal plane theories, like other biomechanical theories, do not accommodate -

- normal trunk bilateral asymmetry $[96,106,107]$,

- normal thoracic spinal axial vertebral rotation [108],

- bilateral skeletal asymmetries of AIS [7],

- some bilateral neural [50,51] and vestibular [55] asymmetries, and

- the systemic and metabolic disorders associated with AIS.

The riders are secondary effects (epiphenomena) [3] and/or multiple factors possibly of different weight in individuals with similar deformities.

Posture - gender and age-specific features. In Novosibirsk, Russia, Sarnadskiy [109] reported on 33,000 children and adolescents from 5-17 years who were screened using computed optical topography. The most significant postural differences between boys and girls were in the sagittal plane. In the transverse plane, from the age of 5 years, the trunk twists in a clockwise direction in boys and girls. By the age of 17 years, the clockwise twisting is preserved in boys, but in girls counterclockwise twisting is prevalent. These twistings are novel phenomena that need investigation.

Classification of postural and spinal disorders. In Novosibirsk, Russia, Sarnadskiy [110] presented a classification of postural and spinal deformities based on experience since 1994 of using computed optical topography for spinal deformities.

Longitudinal evolution of back shape in three planes. In Pern, Russia, Pecherskiy et al. [111] using computed optical topography studied the "preclinical form" (Dudin and Pinchuk) or "dark zone" (Bagnall) of AIS, by evaluating back shape in schoolchildren on three occasions. Seven morphological groups were identified with only $1 / 4$ children maintaining their group and others "migrating" between groups.

Faulty body posture and bilateral asymmetry. In Lodz, Poland, Kluszczynski and Czernicki [112] reported a longitudinal study of 100 children and adolescents examined for body posture in 1997 and again in 2007. In the girls during pubertal growth, thoracic kyphosis decreased as lumbar lordosis increased, with an opposite tendency in boys. Back asymmetry frequency increased in both sexes, left thoracolumbar, right thoracic and left lumbar, as did pelvic asymmetry and functional asymmetry of the right lower limb.

Posterior trunk asymmetry. In Poznan, Poland, Stolinski and Kotwicki [113] reported the use of a Bunnell Scoliometer to measure the angle of trunk rotation (ATR) at three levels (thoracic, main thoracic and lumbar) in a standing forward bending position in 9,500 Primary schoolchildren age 7-10 years

Anterior trunk asymmetry. In Poznan, Poland, Stolinski et al. [114] reported a new parameter, anterior trunk asymmetry index conducted on 50 schoolchildren age 6-7 years.

Transient upper arm length asymmetry associated with right thoracic AIS (RT-AIS). In Nottingham, UK, Burwell et al. [115] in right-handed girls with RT-AIS found that upper arm length asymmetry (right-minusleft) 1) regressed negatively with each of age and years after estimated menarcheal age, 2) was greater than in healthy girls, and 3) correlated significantly with Cobb angle and apical vertebral rotation. The findings have relevance to RT-AIS pathogenesis, and the use of arm span to measure skeletal overgrowth in AIS.

Leg length discrepancy (LLD) in scoliosis patients. In Pescara, Italy, D'Amico et al. [116] using an optoelectronic system on 143 scoliotic patients with a mean LLD of $10 \mathrm{~mm}$, confirmed a previous study that demonstrated the efficacy of under-foot wedge. in LLD correction. 


\section{Sensory and sensorimotor integration disorder and dystonia}

There is increasing evidence for the possibility of an underlying neurological disorder for AIS; this research needs to ne extended. The findings relate to sensory integration [54], sensorimotor integration and dystonia [50,51,53], spinal cord [25,26], brain stem [9], motor control [49], motor cortex [50], supplementary motor area [51], brain white matter [117] as part of the Human Connectome [118], cerebral cortex as a whole [119] and vestibular system [55]. The two papers by Domenech et al. focus attention on bilateral asymmetric activity respectively of motor cortex [50] and supplementary motor area [SMA, 51] as pathomechanisms for idiopathic scoliosis (IS). Reviewing the SMA paper [51] Benoist [120] writes:

"These findings support the hypothesis that a sensorimotor integration underlies the pathogenesis of IS. In addition, as suggested by the authors, these abnormal MRI findings may represent a biomarker of IS disease and open the way to novel therapeutic targets. This paper, winner of the EuroSpine Full Paper Award for 2010, has limitations, which have been summarized in a Reviewer's Comment by Freeman [121].”

Somatosensory and motor evoked potentials. Huber and Rogala [122] in 136 AIS patients before treatment found asymmetrical deficits in both afferent (SEP) and efferent (MEP) transmissions especially at the level of the apical vertebra of the main curvature, but also in $45 / 65$ patients in the brain stem. These findings were related to structural changes in spinal cord and brain stem.

EEGs and peculiarities of brain functioning in AIS. In St Petersburg, Russia, Pinchuk et al. [123] using an original analysis of EEGs revealed a shift of bioelectric activity focus to the left hemisphere in patients with AIS. and more with increasing curve severity that may be prognostic for AIS. This interhemispheric asymmetry was not observed in healthy children 7-14 years, but was found in healthy adolescents at 15-17 years and in adults. In AIS, it represents an earlier maturation than in healthy subjects with the brain playing a more important role in right- than left-sided AIS. They suggest the underlying mechanism is an "overstrain of the central nervous system adaptation-compensation mechanisms during the pubertal period."

Cerebral cortical thickness. In Hong Kong, China, Chu et al. [124] reported findings implying a different thinning pattern of the cerebral cortex during adolescence in patients with AIS; this may be primary (etiopathogenetic) or secondary to the development of the scoliosis.
Postural control. In Poznan, Poland, Wiernicka et al. [125] evaluated static and dynamic postural control to body mass loading (BML) during single and double lower limb stance on respectively a force platform and rolling rocker board. In 30 girls with thoracolumbar idiopathic scoliosis (IS), foot arch shape differently controls static and dynamic balance. compared with 34 healthy girls. IS girls with flattening of the foot and those with foot arch preserved during BML had respectively higher and lower sway pathways than controls.

Back muscle bioelectric activity. In St Petersburg, Russia, Syngayevskaya et al. [126] studied back muscle bioelectric activity in children 10-15 years of age. They found paravertebral muscle activity at the curve apex was higher on the convexity and, in the distal part, higher on the concavity compared with the opposite side. $\mathrm{H}$-reflex and M-responses were studied in relation to curve progression.

\section{Lessons from brain research - brain in a box}

The diversity between the above theories reveals current ignorance about the causation of AIS indicating more integrated knowledge is needed. Like brain research $[127,128]$, most AIS workers are focused on their own corner. In brain research, which generates about 60,000 papers per year, one team in Europe is planning to integrate these discoveries and achieve a comprehensive understanding of the brain; this would be done by building unifying computer models ('brain in a box') for which one billion euros is being sought in 2012 from the European Union's new decade-long 'flagship' initiatives [127] (see Conclusions).

\section{Grand unifying theory for AIS scoliogeny - brain and scoliosis in a box?}

In AIS, the possible creation of a network approach to the pathogenesis by constructing AIS diseasomes [129] was suggested [18]. The attainment of a grand unifying theory for adolescent idiopathic scoliogeny seems unlikely at present. Finite element analysis of spinal models of AIS pathogenesis ('scoliosis in a box') has provided for the testing of specific questions, recently in connection with how accelerated growth profiles may increase scoliosis progression and pose a progressive risk factor [130]. Building a unifying computer model for AIS pathogenesis might be considered using supercomputers with ever increasing memory ('brain and scoliosis in a box').

\section{The biological Higgs - aging, AIS and scoliogeny}

Biologists have recently pondered what fundamental discoveries might match the excitement of the Higgs boson, the so-called 'God Particle' [131]. Some scientists consider that the ability to slow aging would address Higgslike fundamental questions about human life. AIS, we suggest, may be viewed as a disorder of aging processes 
during development. So questions about what pathways control aging - highly unlikely to result from a unitary cause [131,132] - and some age-related diseases, may be relevant to the scoliogeny of AIS (see 9.1.1).

\section{Genetics, epigenetics and AIS scoliogeny}

After mentioning genetics we focus on epigenetics and how it might relate to AIS scoliogeny.

\section{Genetics and the genetic variant hypothesis for complex disease 2012}

Etiology of AIS is poorly understood

Twin studies and observations of family aggregation have revealed significant genetic contributions to idiopathic scoliosis that position AIS among other common disease or complex traits with high heritability [133]. However, despite many investigations, the underlying etiology of idiopathic scoliosis is poorly understood $[6,134]$.

\section{Position for AIS}

Based on gene-linkage studies, candidate gene approach and genome-wide association studies, Wang et al. [5] summarized the then position as follows:

"Recent evidence not only suggests that genetic factors play an important role in the etiology of AIS but also revealed the considerable heterogeneity. Although the continuation of the search for the exact genetic factors is inevitable, it is also very important to look at the functional and biological aspects to allow better understanding of the etiopathogenesis if AIS."

An axial developmental gene (VANGL1) harbours a mutation causing idiopathic scoliosis. In the USA, Wise et al. [135] used next generation sequencing to discover a gene that harbours a mutation causing IS in a three generation family. An excess of mutations of this gene was found in subsequent series of IS patients compared with controls. They comment that VANGL1 participates in a biochemical pathway critical in axial development, specifically controlling neural tube development and spinal cord directionality.

New susceptibility locus for AIS. In the USA, Takahashi et al. [136] through a generation wide and replication study in Japanese, identified SNPs near LBX1 significantly associated with susceptibility of AIS.

Gene profiles, cellular and biochemical endophenotypes of idiopathic scoliosis (IS). In Montreal, Canada, Gorman et al. [137] aiming Ito discover expressed genes among their three endophenotypes (groups 1-3), used a microarray analysis on osteoblasts and peripheral blood mononuclear cells (30 patients with IS, 10 controls), analyzing 38,000 genes. It was found that generally, the expression profiles for groups $2 \& 3$ were similar to each other in contrast to that of group 1, reflecting functional responses to osteopontin.

CHD7 polymorphism in a Central European sample. In Poznan, Poland, Janusz et al. [138] stated that in North America, single SNPs of the CHD7 gene have been shown to be associated with idiopathic scoliosis (IS) susceptibility. In 44 females including IS and controls from Central Europe, no association was found between the CHD7 gene and either susceptibility to IS, or its severity.

Gene polymorphisms and AIS susceptibility. In Nanjing, China, Zhou et al. [139] stated that genome wide association studies suggested that gene polymorphisms of $I L$ 17RC, CHL1, DSCAM, CNTNAP2 are associated with AIS. In a Chinese Han population with AIS, they reported that while $I L-17 R C$ may be a susceptibility gene for AIS, CHL1, DSCAM, CNTNAP2 genes were not associated with AIS.

Gene expression, biomechanical stress and estradiol. In Montreal, Canada, Moldovan et al. [38] demonstrated that biomechanical stress and estradiol are involved in the expression of certain genes in osteoblasts from AIS subjects which could impact curve progression. Using microarray analysis, 86 genes were expressed at relatively higher levels in AIS osteoblasts compared with controls, while 59 genes were expressed at lower levels. The genes are reported to be involved in bone metabolism and embryonic development suggesting various gene interactions and pathways in AIS pathogenesis. The research provided a previously unrecognised list of candidate genes for AIS.

Selection of subjects for genetic association studies for idiopathic scoliosis/. In Poznan, Poland, Harasymczuk et al. [140] after examining English Language articles from 2001-2011, stated that most to-date were not based on common inclusion criteria which is needed.

Large multiplex French family with idiopathic scoliosis (IS). In Montreal, Canada, Moldovan et al. [141] evaluated a large multiplex French family with IS. Within two chromosomal loci linked to IS susceptibility, several novel variants were found; two of these variants co-segregate perfectly with the disease.

\section{AIS Prognostic Test (AIS-PT, Scoliscore)}

Genetic profiling using 53 single nucleotide polymorphisms (SNPs), gene-to-gene interactions, and the patient's initial Cobb angle measurement, produced a score ranging from 1-200 predicting scoliosis curve progression [142-145] and provided a scientific basis for the AIS Prognostic Test (Scoliscore, Axial Biotech, Inc.).

Clinical value of an intermediate risk score with AIS Prognostic test (AIS-PT). In the USA, Ward et al. [146] concluded that within the intermediate score range, individual risks vary tremendously ( $>20$ fold) based on the actual score observed. 
AIS Prognostic Test testing of patients with advanced Cobb angle provides further validation of the test algorithm. In the USA, Nelson et al. [147] showed that patients with advanced Cobb angle showed elevated Ptognostic Test values. None of the patients who progressed to severe curves had low risk scores.

Prognostic testing cannot be applied to all racial groups without modification. In the USA, Ward [148] compared DNA samples from AIS patients with controls from Asian and African ancestry. DNA markers were related to AIS progression and vary by race. Differences in gene variants will translate into differences in the underlying chemistry of AIS causing different clinical expression.

Prognostic Test scores are higher in patients who fail orthotic treatment for AIS. In Canada, Ogilvie et al. [149] stated that although the DNA-based AIS Prognostic Test was not designed to predict brace success or failure, the data show that underlying genetic factors may play an important role in response to bracing.

The use of $3 D$ spinal parameters to differentiate between progressive and non-progressive AIS curves at the first visit Nault et al. [150] at the first clinic visit, confirmed there are morphological differences between progressive and non-progressive AIS curves; these include axial rotation, hypokyphosis, plane of maximal curvature and torsion of the spine. The findings are claimed to underscore the importance of the torsional aspect of the deformity occurring at the junctional zone below the main curve. Wedging does not seem to be related to progression at this early stage.

Genetic variant hypothesis and non-genetic factors for complex disease

Butcher and Beck [151] write:

"A spate of high-powered genome-wide association studies (GWAS) have recently identified numerous single-nucleotide polymorphisms (SNPs) robustly linked with complex disease. Despite interrogating the majority of common human variation, these SNPs only account for a small proportion of the phenotypic variance, which suggests genetic factors are acting in concert with non-genetic factors. Although environmental measures are logical covariants for genotype-phenotype investigations, another non-genetic intermediary exists, epigenetics."

\section{Epigenetics - perspective for AIS}

Definition and epigenetic modifications

Epigenetics is generally defined as information heritable during cell division but not contained within the
DNA sequence itself, termed epigenetic modifications $[18,152,153]$.

There are the three major ways organisms alter their DNAs inherited messages [153,154]:

- enzymes methylate DNA to modulate transcription;

- histone modifications and nucleosome positioning to induce or repress target sequences; and

- non-coding small RNAs (including microRNAs and short interfering RNAs) which attach themselves to messenger RNA to modify the expression of specific genes.

\section{DNA methylation}

According to Talens et al. [155]:

"DNA methylation may be the most suitable epigenetic mark for large-scale epidemiological studies, since methyl groups are covalently bound to $C p G$ dinucleotides and are not lost during routine DNA extraction, unlike histone modifications. This opens the possibility of exploiting existing DNA biobanks for research purposes, to discover epigenetic risk factors for complex disease."

\section{Epigenetics at the epicenter of modern medicine}

Epigenetics evaluates factors concerned with gene expression in relation to environment, disease, normal development and aging, with a complex regulation across the genome during the first decade of life [16-18].

Feinberg [13] writes:

"Epigenetics, the study of non-DNA sequence-related heredity, is at the epicenter of modern medicine because it can help to explain the relationship between an individual's genetic background, the environment, aging, and disease..."

\section{Environmental factors and AIS}

In the last 20 years, sporadic reports have suggested environmental factors are involved in the etiopathogenesis and phenotypic expression in some subjects with AIS. We review the evidence elsewhere [18].

Truncal asymmetry and maternal age at birth. In Athens, Greece, Grivas et al. [156] reported evidence from schoolchildren that maternal age through epigenetic mechanisms, may influence the occurrence of truncal asymmetry during growth in males more than females.

\section{Hypothesis of developmental instability for scoliosis} Speculation that genetic and environmental factors are involved the etiopathogenesis of idiopathic scoliosis $[157,158]$ was further developed by Goldberg and colleagues [92,93] 
who suggested that scoliosis is caused by environmental stress causing developmental instability:

\section{Heated indoor swimming pools, infants and AIS as a delayed epigenetic effect}

McMaster et al. $[159,160]$ reported a statistically significant correlation between the introduction of infants to heated indoor swimming pools and the development of AIS. A neurogenic hypothesis was formulated to explain how neurotoxins produced by chlorine may act on the infant's immature central nervous system with an implication of the brain's barrier and cerebral spinal fluid being involved. The delayed epigenetic effects with the bony trunk deformity of AIS do not become evident until adolescence [161]. There may be many such environmental factors acting in the first year of life to initiate AIS and differing around the world (see Figure 1). Whatever the effects, the neurotoxic products may have on the immature brain, the process of puberty with its increased growth velocity is suggested to play a role in the delayed phenotypic expression of AIS [101,162].

Elsewhere we outline and comment on etiopathogenetic concepts as they may relate to normal spine development and AIS pathogenesis [18].

\section{Human development - normal life history phases and epigenetics}

Developmental plasticity and epigenetic programming

Reviewing child health, developmental plasticity and epigenetic programming, Hochberg et al. [11] describe how transition between life-history phases defines pre-adult phases of predictive adaptive responses (plasticity) (Figure 1).

- Infancy-to-childhood (I/C) transition is associated with GH-IGFI axis activation that affects adult height;

- Childhood-to-juvenility (C/J) transition affects body composition, adiposity rebound and circulating leptin levels.

\section{Life history phases, epigenetics and AIS}

We applied this concept speculatively to AIS pathogenesis in susceptible girls [163].

Body composition and nutritional status. In Katowice, Poland, Matusik et al. [164] evaluated nutritional status of children and adolescents with idiopathic scoliosis, early onset $(n=25)$ and late onset $(n=34)$. Overweight and obesity had the same prevalence as the normal population, Nutritional abnormalities were more common in boys. Early onset patients are thinner than the late-onset group.

\section{Environment, non-communicable diseases} Idiopathic chronic non-communicable diseases (NCDs) Types of NCDs, risk factors and prevention

Common chronic NCDs include obesity, diabetes, cardiovascular disease, respiratory disease, cancer and schizophrenia attributed to genetic and environmental factors [12] with a pathogenetic link being defined between obesity and cancer [165]. Risk factors for NCDs include age, unhealthy diet, smoking, alcohol abuse, chemicals, and lack of physical activity $[131,161,166,167]$, the last possibly by impairing each of autophagy, mitochondrial upgrade and energy production [168]. In studying the prevention of NCDs, there is a move away from adults to mother, father, pregnancy and child [169], with recent research revealing a link between gene promoter methylation in umbilical cord tissue and later adiposity (Figure 2) [170].

\section{AIS as an NCD?}

Although AIS is not regarded as an NCD, like them and particularly like obesity, it is often associated with whole organism but opposite metabolic phenomena, namely lower body mass index (BMI) [171,172], lower circulating leptin levels [78,79], and other systemic disorders [59-64,66-72].

\section{AIS, obesity, hypothalamic sensitivity and resistance to leptin}

In the leptin-hypothalamic-sympathetic nervous system (LHS) concept for AIS pathogenesis of girls, scoliosis initiation is attributed to increased hypothalamic sensitivity to leptin [for central leptin activity see $83,173,174$ ] with sympathoactivation becoming asymmetric as an adverse hormetic effect $[7,175,176]$; this places AIS with lower BMI at the opposite end of the spectrum from the central leptin resistance concept for obesity [7]. The putative asymmetric sympathoactivation is viewed as one mechanism initiating the costo-vertebral asymmetry of right thoracic AIS in girls $[7,28]$ that produces the major phenotypic abnormality, namely the scoliosis of a whole organism (systemic) disorder.

\section{Methodological application of epigenetics to epidemiological studies}

Some methods in DNA methylation profiling are reported by Zuo et al. [177]. The application of epigenetic methods to epidemiological studies is discussed here in relation to some other diseases, and then how these methods might be applied to AIS.

\section{Applying epigenetic methods to some other diseases}

Mazzio and Soliman [17] write:

"One of the greatest challenges in the study of epigenetics as it relates to disease is the 


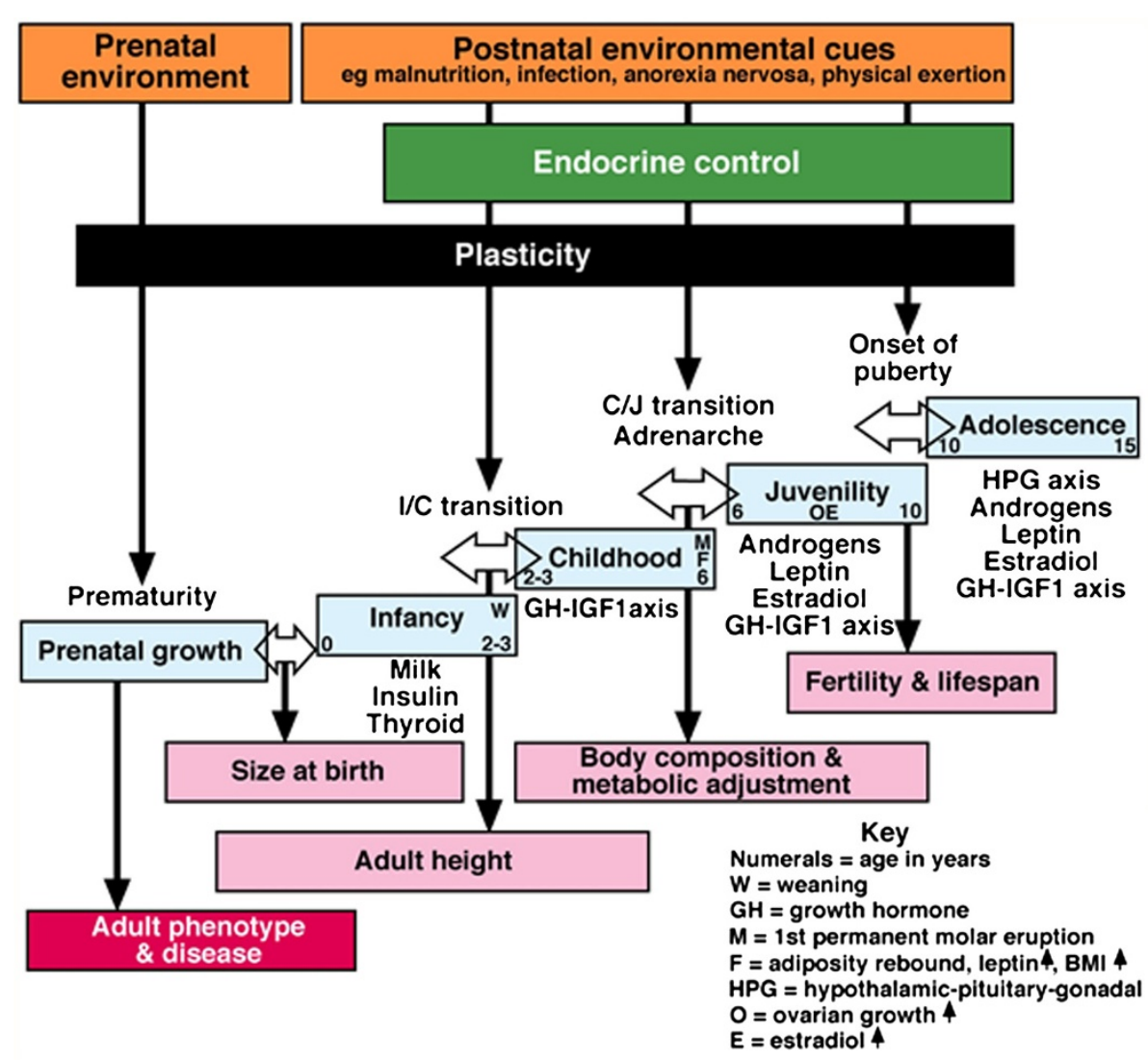

Figure 1 Pre-adult periods of adaptive plasticity in the transition between life history phases (from Burwell et al. [163] modified from Hochberg et al. [11]).

enormous diversity of proteins, histone modifications and DNA methylation patterns associated with each unique maladaptive phenotype. This is further complicated by a limitless combination of environmental cues that could alter the epigenome of specific cell types, tissues, organs and systems."

We examine here what has been found epigenetically for -

- Silver- Russell syndrome,

- Idiopathic chronic non-communicable diseases (NCDs) some of which afflict children,

Silver-Russell syndrome (SRS)

Silver-Russell syndrome is a clinically and genetically heterogeneous congenital disorder characterized by severe growth retardation [178] with bilateral skeletal asymmetry and genital anomalies. Bruce et al. [179] found a dose-response relationship between the degree of H19 hypomethylation and phenotype severity in SRS. The association between severe H19 hypomethylation and specific anomalies of the spine, elbows, hands and feet, and genital defects, was shown for the first time.

Idiopathic non-communicable diseases (NCDs)

Fixed genomic variation

According to Godfrey et al. [170]:

"Fixed genomic variation explains only a small proportion of the risk of adiposity in animal models; maternal diet alters offspring body composition, accompanied by epigenetic changes in metabolic control genes. Little was known about whether such processes operate in humans."

Gene promoter methylation in umbilical cord tissue at birth and later adiposity

Using Sequenom MassARRAY, Godfrey et al. [170] measured the methylation status of $68 \mathrm{CpGs} 5^{\prime}$ from five 


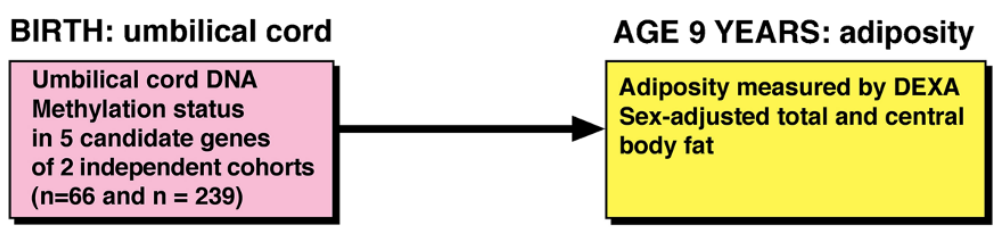

FINDINGS

Greater methylation of retinoid $X$ receptor-alpha ( $R X R A)$ gene correlates strongly with -

(1) Lower maternal intake of carbohydrate in early pregnancy

(2) Greater adiposity at 9 years

\section{CONCLUSION}

Neonatal epigenetic measurements may be useful predictors of later adiposity and other phenotypic outcomes

Figure 2 Diagram summarizing the study of Godfrey et al. [170] who state that genome-wide association studies showed fixed genetic variation makes little contribution to the risk of obesity, heart disease, or diabetes. Godfrey et al. conclude that their findings "...raise the possibility that the developmental environment component may be equally or more important." We suggest that after consideration of the selection of appropriate candidate genes, umbilical cords may be stored and the children later evaluated for trunk deformity of both AIS and normal trunk asymmetry $[96,106,107]$.

candidate genes in umbilical cord tissue DNA of healthy neonates (Figure 2). Methylation varied greatly at particular CpGs. They related methylation status to maternal pregnancy diet and to child's adiposity at age 9 years (by dual energy X-ray absorptiometry) with replication established in a second independent cohort. They concluded that: (1) a substantial component of metabolic disease risk has a prenatal developmental basis, and (2) perinatal epigenetic analysis may have utility in identifying individual vulnerability to later obesity and metabolic disease.

\section{Suggestions for applying epigenetic methods to AIS etiopathogenesis}

Methylation of candidate genes - cross-sectional study

As for Silver-Russell syndrome [178,179], we suggest that the possible selection of appropriate candidate genes and evaluating their methylation status in relation to physical and other characteristics of AIS subjects be considered. Familial and sporadic AIS might be evaluated.

Methylation of DNA in umbilical cord tissue at birth and later AIS - longitudinal study

As for adiposity (Figure 2) [170], the stored umbilical cords of children who later show trunk distortion $[96,106,107]$ and AIS deformity may be evaluated for their DNA methylation status, with familial and sporadic AIS again evaluated.
Methylation in buccal smear DNA and later AIS longitudinal study

An evaluation might be considered using buccal smear DNA starting, say at 5 years, with familial and sporadic AIS being evaluated.

\section{The future - memorandum of understanding for AIS scoliogenic research?}

We suggest consideration be given to forming a group to work out details of a possible international collaborative effort for epigenetic scoliogenic research on AIS, perhaps initially preparing a Memorandum of Understanding.

\section{Conclusions}

Extracts of the selected AIS scoliogeny papers presented at the 2012 IRSSD and SRS Meetings and arranged in a review article [1] -

- reveal where progress is currently being made, and

- suggest fields where the focus is becoming clearer, and/or needs enlarging.

The latter include includes:

1. Preclinical form, dark zone and prodromal stage of AIS.

2. Human development and skeletal growth.

3. Back shape, back muscle activity, posture and gait.

4. Radiology. 
5. Central nervous system, brain, vestibular system and spinal cord.

6. Hormones and receptors, including oestrogens, melatonin, leptin, ghrelin and neurohormonal regulation.

7. Melatonin receptors.

8. Melatonin-signalling dysfunction.

9. Osteopontin, CD44, PTPx, HSJ and chaperone molecules.

10. Osteoblasts, biomechanical stress and oestrogens.

11. Bone matrix, mineralization and osteopenia.

12. Bilateral skeletal asymmetries.

13. Simulation.

14. Genetics.

15. Epigenetics.

16. Prognosis.

17. Theory refinement and formulation.

18. As for brain research [127], future work on AIS etiopathogenesis requires research at different levels, integration of information, simulation and collaboration [180]. The European Union announced in January 2013 euros 500 million (US\$670 million) for the Human Brain Project (2013-2023) [181], with the goal of drawing together all existing knowledge of the human brain employing supercomputer-based models and simulations to reconstruct the brain. In the USA. a decade-long programme is planned to examine brain function aiming to build a comprehensive activity map, and seeking to do for the brain what the Human Genome Project did for [182,183].

19. In AIS, the ultimate hope is to prevent the occurrence or progression of the spinal deformity with non-invasive treatment, possibly medical. This might be attained by personalised polymechanistic preventive therapy targeting the appropriate etiology, or etiopathogenetic pathways, to avoid fusion and maintain spinal mobility.

\section{Competing interests}

The authors declare that they have no competing interests.

\section{Authors' contribution}

The original "Whither" article was written by GB and presented at IRSSD by PD. JC initiated this review of the selected scoliogenic presentations at the 2012 IRSSD Meeting to which the 2012 SRS Meeting was added by GB. Copies of the Final SRS Program were given to GB by Mrs MJ MCMaster and Dr NS Harshaavardhana. The selection of abstracts for inclusion was made by GB and discussed with JC, PD. AM and TG. All authors contributed their professional skills to the inclusions of the text. All authors have read and approved the final manuscript.

\section{Acknowledgements}

We thank the authors of their presentations whose abstracts we have summarized. If other authors consider that their work should have been included we apologise for this omission.

We thank Mr Lyndon Cochrane for the art work of the original "Whither" article.

\section{Author details}

${ }^{1}$ Centre for Spinal Studies and Surgery, Nottingham University Hospitals Trust, Queen's Medical Centre Campus, Derby Road, Nottingham NG7 2UH, UK. ${ }^{2}$ University of Liverpool, Ashton Street, Liverpool L69 3GE, UK.

${ }^{3}$ Staffordshire University, Leek Road, Stoke-on-Trent ST4 2DF, UK. ${ }^{4}$ Royal Liverpool Children's Hospital, Eaton Road, Liverpool L12 2AP, UK.

${ }^{5}$ Department of Orthopaedic Surgery, King's Mill Hospital, Sutton Road, Mansfield NG17 4JL, UK. 'Department of Trauma and Orthopaedics, "Tzanio" General Hospital, Tzani and Afendouli 1 st, Piraeus 18536, Greece.

${ }^{7}$ Department of Orthopaedics \& Traumatology, The Joint Scoliosis Research Centre of the Chinese University and Nanjing University, Prince of Wales Hospital, The Chinese University of Hong Kong, Hong Kong, SAR, China.

Received: 29 November 2012 Accepted: 9 February 2013

Published: 28 February 2013

\section{References}

1. Burwell RG, Dangerfield PH: Whither the etiopathogenesis (and scoliogeny) of adolescent idiopathic scoliosis? Stud Health Technol Inform 2012, 176:3-19.

2. Sevastik J: Animal experiments in scoliosis. A critical review. Eur J Exper Musculoskel Res 1993, 2:51-60.

3. Cheung KM, Wang T, Qiu GX, Luk KD: Recent advances in the aetiology of adolescent idiopathic scoliosis. Int Orthop 2008, 32(6):729-734.

4. Burwell RG, Dangerfield PH, Freeman BJC: Concepts on the pathogenesis of adolescent idiopathic scoliosis. Bone growth and mass, vertebral column, spinal cord, brain, skull, extra-spinal left-right skeletal length asymmetries, disproportions and molecular pathogenesis. Stud Health Technol Inform 2008, 135:3-52.

5. Wang WJ, Yeung HY, Chu WC, Tang NL, Lee KM, Qiu Y, Burwell RG, Cheng $J C:$ Top theories for the etiopathogenesis of adolescent idiopathic scoliosis. J Pediatr Orthop 2011, 31:S14-S27.

6. Wise CA, Gao X, Shoemaker S, Gordon D, Herring JA: Understanding genetic factors in idiopathic scoliosis, a complex disease of childhood. Curr Genomics. 2008, 9(1):51-59.

7. Burwell RG, Aujla RK, Grevitt MP, Dangerfield PH, Moulton A, Randell TL, Anderson SI: Pathogenesis of adolescent idiopathic scoliosis in girls a double neuro-osseous theory involving disharmony between two nervous systems, somatic and autonomic expressed in the spine and trunk: possible dependency on sympathetic nervous system and hormones with implications for medical therapy. Scoliosis 2009, 4:24.

8. Burwell RG, Dangerfield PH: Adolescent idiopathic scoliosis: hypotheses of causation. In Etiology of Adolescent Idiopathic Scoliosis: Current Trends and Relevance to New Treatment Approaches, State of the Art Reviews: Spine. Edited by Burwell RG, Dangerfield PH, Lowe TG, Margulies JY. Philadelphia: Hanley \& Belfus Inc; 2000. 14(2):319-333.

9. Lowe TG, Edgar M, Margulies JY, Miller NH, Raso VJ, Reinker KA, Rivard C-H: Current concepts review: etiology of idiopathic scoliosis: current trends in research. J Bone Joint Surg Am 2000, 82-A:1157-1168.

10. Acaroglu E, Bobe R, Enouf J, Marcucio R, Moldovan F, Moreau A: The metabolic basis of adolescent idiopathic scoliosis, report of the "metabolic" workgroup of the Fondation Yves Cotrel. Eur Spine J 2011 , 21(6):1033-1042

11. Hochberg Z, Feil R, Constancia M, Fraga M, Junien C, Carel JC, Boileau P, Le Bouc Y, Deal CL, Lillycrop K, Scharfmann R, Sheppard A, Skinner M, Szyf M, Waterland RA, Waxman DJ, Whitelaw E, Ong K, Albertsson-Wikland K: Child health, developmental plasticity, and epigenetic programming. Endocr Rev 2011, 32(2):159-224

12. Rappaport SM, Smith MT: Epidemiology: Environment and disease risks. Science 2010, 330(6003):460-461.

13. Feinberg AP: Epigenetics at the epicenter of modern medicine. JAMA 2008, 299(11):1345-1350

14. Carey N: The epigenetics revolution. London: Icon Books; 2011:339.

15. Francis RC: Epigenetics, the ultimate mystery of inheritance. New York: WW Norton \& Company; 2011:234

16. Feil R, Fraga MF: Epigenetics and the environment: emerging patterns and implications. Nat Rev Genet 2012, 13(2):97-109.

17. Mazzio EA, Soliman KF: Basic concepts of epigenetics: Impact of environmental signals on gene expression. Epigenetics 2012, 7(2):119-130. 
18. Burwell RG, Dangerfield PH, Moulton A, Grivas TB: Adolescent idiopathic scoliosis (AIS), environment, exposome and epigenetics: a molecular perspective of postnatal normal spinal growth and the etiopathogenesis of AIS with consideration of a network approach and possible implications for medical therapy. Scoliosis 2011, 6(1):26.

19. Guo X, Chau W-W, Chan YL, Cheng J-C-Y, Burwell RG, Dangerfield PH: Relative anterior spinal overgrowth in adolescent idiopathic scoliosis result of disproportionate endochondral-membranous bone growth? Summary of an electronic focus group debate of the IBSE. Eur Spine J 2005, 14:862-873.

20. Janssen MMA, Vincken EL, Van R, Vrtovec T, Kemp B, Viergever MA, Bartels LW, Castelein RM: Sagittal spinal profile and spinopelvic balance in parents of scoliotic children, as compared to normal controls. Stud Health Technol Inform 2012, 176:463.

21. Janssen MMA, Vincken KL, Vrtovec T, Kemp B, Viergever MA, Bartels LW, Castelein RM: Sagittal spinal profile and spinopelvic balance in parents of scoliotic children, as compared to normal controls. In Scoliosis Research Society $47^{r d}$ Annual Meeting and Course, Chicago, Illinois, USA, September 58th. 2012:145

22. Van Loon PJ: Ever-present factors in healthy children that can deform their spines, Opposition to Dickson's paradigm on lordosis. Stud Health Technol Inform 2012, 176:63-67.

23. Van Loon PJ, Roukens M, Thunnissen FB, Munneke J: A similar approach in bracing of adolescent scoliosis and kyphosis with the use of growth itself in Thoracolumbar Lordotic Intervention (TLI). Stud Health Technol Inform 2012, 176:68-72.

24. Janssen MMA, Vrtovec T, Pernus F, Oner FC, Veereecke EE, Channon AJ, Viergever MA, Vincken KL, Castelein RM: The pelvic lordosis: an essential adaptation in human evolution, and a determinant of spinopelvic alignment. Stud Health Technol Inform 2012, 176:462.

25. Chu WCW, Lam WWM, Ng BKW, Lam T-p, Lee K-m, Guo X, Cheng JCY, Burwell RG, Dangerfield PH, Jaspan T: Relative shortening and functional tethering of spinal cord in adolescent scoliosis - Result of asynchronous neuro-osseous growth? Summary of an electronic focus group debate of the IBSE. Scoliosis 2008, 3:8:48-7161-3.

26. Lao LF, Shen JX, Chen ZG, Wang YP, Wen XS, Qiu GX: Uncoupled neuroosseous growth in adolescent idiopathic scoliosis? A preliminary study of 90 adolescents with whole-spine three-dimensional magnetic resonance imaging. Eur Spine J 2011, 20(7):1081-1086.

27. Dudin M, Pinchuk D: Typical and atypical AIS, Pathogenesis. Stud Health Technol Inform 2012, 176:139-145

28. Sevastik J, Burwell RG, Dangerfield PH: A new concept for the etiopathogenesis of the thoracospinal deformity of idiopathic scoliosis: summary of an electronic focus group debate of the IBSE. Eur Spine J 2003, 12:440-450.

29. Janssen MM, Kouwenhoven JW, Castelein RM: The role of posteriorly directed shear loads acting on a pre-rotated growing spine: a hypothesis on the pathogenesis of idiopathic scoliosis. Stud Health Technol Inform 2010, 158:112-117.

30. Castelein RM: Pre-existent rotation of the normal spine at different ages and its consequences for the scoliotic mechanism. Stud Health Technol Inform 2012, 176:20-25.

31. Schlosser $T$, Janssen M, Attrach $H$, Viergever M, Vincken $K$, Castelein R: Systematic analysis of of the neurocentral junction (NCJ) in the normal infantile, juvenile and adolescent spine. Stud Health Technol Inform 2012, 176:482.

32. Karnezis IA: Flexural-torsional buckling initiates idiopathic scoliosis. Med Hypotheses 2011, 77(5):924-926.

33. Stokes IAF, Burwell RG, Dangerfield PH: Biomechanical spinal growth modulation and progressive adolescent scoliosis - a test of the 'vicious cycle' pathogenetic hypothesis: Summary of an electronic focus group debate of the IBSE. Scoliosis 2006, 1:16:-7161-1-16.

34. Bettany-Saltikov J, Cole L: The effect of frontpacks, shoulder bags and handheld bags on 3D back shape and posture in young university students: an ISIS2 study. Stud Health Technol Inform 2012, 176:117-121.

35. Raison M, Ballaz L, Detrembleur C, Mahaudens P, Lebleu J, Fisette P, Mousny M: Lombo-sacral joint efforts during gait: comparison between healthy and scoliotic subjects. Stud Health Technol Inform 2012, 176:113-116.

36. Menard A-L, Valteau B, Londono I, Moldovan F, Gromard G, Villemure I: Influence of dynamic loading parameters on bone growth modulation. Stud Health Technol Inform 2012, 176:469.
37. Rizza R, Liu XC, Thometz J: The in-vivo effect of torque on growth in caudal vertebrae. Stud Health Technol Inform 2012, 176:209-212.

38. Moldovan F, Villemure I, Fendri K, Grimard G, Zaouter C, Parent S, Moreau A, Labelle H, Patten SA: Adolescent idiopathic scoliosis(AIS): metabolic factors, biomechanical stress and estrogen impact. Stud Health Technol Inform 2012, 176:452.

39. Karski T: The etiology of the so-called idiopathic scoliosis. New classification (2001-2004-6). The new rehabilitation treatment. Lublin: Prophylaxis; 2011.

40. Karski T: Present day explanation of the clinical signs in the biomechanical aetiology of the so-called idiopathic scoliosis (19952011). The relationship between the "model of hips movement" and the character of scoliosis; three groups and four types. The causative role of "gait" and "standing "at ease" on the right leg". Stud Health Technol Inform 2012, 176:133-138.

41. Taylor TFK, Melrose J: The role of the intervertebral disc in adolescent idiopathic scoliosis. In Etiology of Adolescent Idiopathic Scoliosis: Current Trends and Relevance to New Treatment Approaches, State of the Art Reviews: Spine. Edited by Burwell RG, Dangerfield PH, Lowe TG, Margulies JY. Philadelphia: Hanley \& Belfus Inc; 2000. 14(2):359-369.

42. Antoniou J, Arlet V, Goswami T, Aebi M, Alini M: Elevated synthetic activity in the convex side of scoliotic intervertebral discs and endplates compared with normal tissues. Spine 2001, 26(10):E198-E206.

43. Yu J, Fairbank JC, Roberts S, Urban JP: The elastic fiber network of the annulus fibrosus of the normal and scoliotic human intervertebral disc. Spine 2005, 30(16):1815-1820.

44. Bertram H, Steck E, Zimmerman G, Chen B, Carstens C, Nerlich A, Richter W: Accelerated intervertebral disc degeneration in scoliosis versus physiological ageing develops against a background of enhanced anabolic gene expression. Biochem Biophys Res Commun 2006, 342(3):963-972.

45. Grivas TB, Vasiliadis E, Malakasis M, Mouzakis V, Segos D: Intervertebral disc biomechanics in the pathogenesis of idiopathic scoliosis. Stud Health Technol Inform 2006, 123:80-83.

46. Will RE, Stokes IA, Qiu X, Walker MR, Sanders JO: Cobb angle progression in adolescent scoliosis begins at the intervertebral disc. Spine (Phila Pa 1976). 2009, 34(25):2782-2786.

47. Hristova GI, Jarzem P, Ouellet JA, Roughley PJ, Epure LM, Antoniou J, Mwale $\mathrm{F}$ : Calcification in human intervertebral disc degeneration and scoliosis. J Orthop Res 2011, 29(12):1888-1895. doi:10.1002/jor.21456.

48. Grivas TB, Vasiliadis ES, Triantafyllopolous G, Kaspiris A: A comprehensive model of idiopathic scoliosis (IS) progression, based on the pathobiomechanics of the deforming "three joint complex". Scoliosis 2009, 4:Suppl 2.

49. Herman R, Mixon J, Fisher A, Maulucci R, Stuyck J: Idiopathic scoliosis and the central nervous system: a motor control problem. The Harrington Lecture, 1983. Scoliosis Research Society. Spine 1985, 10(1):1-14.

50. Doménech J, Tormos JM, Barrios C, Pascual-Leone A: Motor cortical hyperexcitability in idiopathic scoliosis: could focal dystonia be a subclinical etiological factor? Eur Spine J 2010, 19(2):223-230.

51. Domenech J, García-Martí G, Martí-Bonmatí L, Barrios C, Tormos JM, PascualLeone A: Abnormal activation of the motor cortical network in idiopathic scoliosis demonstrated by functional MRI. Eur Spine J 2011, 20(7):10691078.

52. Yu WS, Chan KY, Yu FWP, Yeung HY, Lee KM, Ng KW, Qiu Y, Lam TP, Cheng JCY: Lower handgrip strength ingirls with adolescent idiopathic scoliosis (AIS) a case control study. Stud Health Technol Inform 2012, 176:475.

53. Dalleau G, Damavandi M, Leroyer P, Verkindt C, Rivard CH, Allard P: Horizontal body and trunk center of mass offset and standing balance in scoliotic girls. Eur Spine J 2011, 20(1):123-128.

54. Beaulieu M, Toulotte C, Gatto L, Rivard CH, Teasdale N, Simoneau M, Allard $\mathrm{P}$ : Postural imbalance in non-treated adolescent idiopathic scoliosis at different periods of progression. Eur Spine J 2009, 18(1):38-44.

55. Shi L, Wang D, Chu WC, Burwell RG, Wong TT, Heng PA, Cheng JC: Automatic MRI segmentation and morphoanatomy analysis of the vestibular system in adolescent idiopathic scoliosis. Neuroimage 2011, 54(Suppl 1):S180-S188.

56. Chu WCW, Shi L, Wang D, Cheng JCY: Computational morphometry of semicircular canals in adolescent idiopathic scoliosis (AIS) based on high- resolution MR images. Stud Health Technol Inform 2012, 176:480.

57. Veldhuizen AG, Wever DJ, Webb PJ: The aetiology of idiopathic scoliosis: biomechanical and neuromuscular factors. Eur Spine J 2000, 9(3):178-184. 
58. Burwell RG, Freeman BJC, Dangerfield PH, Aujla RK, Cole AA, Kirby AS, Polak F, Pratt RK, Webb JK, Moulton A: Etiologic theories of idiopathic scoliosis: neurodevelopmental concept of maturational delay of the CNS body schema ("body-in-the-brain"). Stud Health Technol Inform 2006, 123:72-79.

59. Lowe TG, Burwell RG, Dangerfield PH: Platelet calmodulin levels in adolescent idiopathic scoliosis: can they predict curve progression and severity? Summary of an electronic focus group debate of the IBSE. Eur Spine J 2004, 13:257-265.

60. Burwell RG, Dangerfield PH: Pathogenesis of progressive adolescent idiopathic scoliosis. Platelet activation and vascular biology in immature vertebrae: an alternative molecular hypothesis. Acta Orthop Belg 2006, 72:247-260.

61. Machida M, Dubousset J, Imamura Y, Miyashita Y, Yamada T, Kimura J: Melatonin: A possible role in pathogenesis of adolescent idiopathic scoliosis. Spine 1996, 21(10):1147-1152.

62. Machida M: Cause of idiopathic scoliosis. Spine 1999, 24(24):2576-2583.

63. Dubousset J, Machida M: Possible role of the pineal gland in pathogenesis of idiopathic scoliosis: experimental and clinical studies. Bull de l'Acad Nat de Méd 2010, 185:593-602. discussion 602-604 (French).

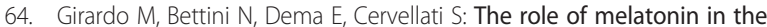
pathogenesis of adolescent idiopathic scoliosis (AIS). Eur Spine J 2011, Suppl 1:S68-S74.

65. Yim APY, Sun GQ, Yeung HY, Lee KM, Ng KW, Lam TP, Qiu Y, Cheng JCY: Abnormally lower expression of melatonin receptor in osteoblasts of adolescent idiopathic scoliosis girls. Stud Health Technol Inform 2012, 176:447.

66. Moreau A, Wang DS, Forget S, Azeddine B, Angeloni D, Fraschini F, Labelle $\mathrm{H}$, Poitras B, Rivard C-H, Grimard G: Melatonin signaling dysfunction in adolescent idiopathic scoliosis. Spine 2004, 29(16):1772-1781.

67. Azeddine B, Letellier K, Wang da S, Moldovan F, Moreau A: Molecular determinants of melatonin signaling dysfunction in adolescent idiopathic scoliosis. Clin Orthop Relat Res 2007, 462:45-52.

68. Azeddine B, Franco A, Rompré PH, Roy-Gagnon M-H, Turgeon I, Boiro MS, Blain S, Boulanger H, Wang DS, Bagnall KM, Poitras B, Labelle HLL, Rivard CH, Grimard G, Ouellet J, Parent S, Moreau A: High circulating levels of osteopontin are associated with idiopathic scoliosis onset and spinal deformity progression [abstract]. In Proceedings of Pediatric Orthopaedic Society of North America $25^{\text {th }}$ Anniversary 2009 Annual Meeting Boston, Massachusetts, April 30-May 2. Boston: Marriott Copley Place; 2009:128.

69. Moreau A, Franco A, Azeddine B, Rompré PH, Roy-Gagnon M-H, Bagnall KM, Poitras B, Labelle HLL Rivard C-H, Grimard G, Ouellet J, Parent S: High circulating levels of osteopontin are associated with idiopathic scoliosis onset and spinal deformity progression [abstract]. In Scoliosis Research Society $44^{\text {th }}$ Annual Meeting and Course, San Antonio, Texas, USA, September 23-26. 2009:109.

70. Moreau A, Akoumé-Ndong MY, Azeddine B, Franco A, Rompré PH, RoyGagnon MH, Turgeon I, Wang D, Bagnall KM, Poitras B, Labelle H, Rivard CH, Grimard G, Ouellet J, Parent S, Moldovan F: Molecular and genetic aspects of idiopathic scoliosis, Blood test for idiopathic scoliosis. Orthopade 2009, 38(2):114-116. 118-21.

71. Akoume MY, Azeddine B, Turgeon I, Franco A, Labelle H, Poitras B, Rivard CH, Grimard G, Ouellet J, Parent S, Moreau A: Cell-based screening test for idiopathic scoliosis using cellular dielectric spectroscopy. Spine (Phila Pa 1976). 2010, 35(13):E601-E608.

72. Moreau A: Interview with Dr A Moreau, creator of Scoliosis blood test. http:// www.scoliosis.org/forum/showthread.php?10705-Interview-with-Dr-AlainMoreau-creator-of-Scoliosis-blood-test. (Accessed 20 April 2012).

73. Sun GQ, Lam TP, Bobby NG, Yim PY, Lee KM, Moreau A, Qiu YY, Cheng JCY: High osteopontin plasma level associated with abnormal cortical bone mineral density in girls with adolescent idiopathic scoliosis. Stud Health Technol Inform 2012, 176:457.

74. Elbakry M, Taheri M, Bouhank S, Akoume M, Moreau A: Identification of key disease-modifying factors in adolescent idiopathic scoliosis. Stud Health Technol Inform 2012, 176:449.

75. Leboeuf D, Letellier K, Alos N, Edery P, Moldovan F: Do estrogens impact adolescent idiopathic scoliosis? Trends Endocrinol Metab 2009, 20(4):147-152.

76. Lombardi G, Akoume MY, Colombini A, Moreau A, Banfi G: Biochemistry of adolescent idiopathic scoliosis. Adv Clin Chem 2011, 54:165-182.

77. Rusin B, Kotwicki T, Głodek A, Andrusiewicz M, Urbaniak P, Kotwicka M: Estrogen receptor 2 expression in back muscles of girls with idiopathic scoliosis - relation to radiological parameters. Stud Health Technol Inform 2012, 176:59-62

78. Qiu Y, Sun X, Qiu X, Li W, Zhu Z, Zhu F, Wang B, Yu Y, Qian B: Decreased circulating leptin level and its association with body and bone mass in girls with adolescent idiopathic scoliosis. Spine 2007, 32(24):2703-2710

79. Liu Z, Tam EM, Sun GQ, Lam TP, Zhu ZZ, Sun X, Lee KM, Ng TB, Qiu Y, Cheng JC, HY Yn: Abnormal leptin bioavailability in adolescent idiopathic scoliosis - an important new finding. Spine (Phila Pa 1976). 2012, 37(7): 599-604.

80. Tam EMS, Yu FWP, Liu Z, Lam TP, Ng BKW, Lee KM, Yong Q, Cheng JCY: Association of low volumetric bone mineral density with leptin and soluble leptin receptor in girls with adolescent idiopathic scoliosis. Stud Health Technol Inform 2012, 176:470.

81. Tam EMS, Yu FWP, Hung WWY, Liu Z, Lam TP, Ng BKW, Lee KM, Yong Q, Cheng JC: Are volumetric bone mineral density and bone microarchitecture in adolescent idiopathic scoliosis associated with leptin and soluble leptin receptor? In Scoliosis Research Society $47^{\text {rd }}$ Annual Meeting and Course, Chicago, Illinois, USA, September 5-8th. 2012:91-92.

82. Tam EMS, Yeung HY, Liu Z, Lam TP, Ting T, Lok JYF, Ng BKW, Lee KM, Yong $Q$, Cheng JCY: Elevated soluble leptin receptor level and association with body composition in girls with adolescent idiopathic scoliosis. Stud Health Technol Inform 2012, 176:472.

83. Wu T, Sun X, Zhu Z, Zheng X, Qian B, Zhu F, Cheng JC, Qiu Y: Role of high central leptin activity in a scoliosis model created in bipedal amputated mice. Stud Health Technol Inform 2012, 176:31-35.

84. de Gouzy S, Gennero I, Accobled H, Salles J-P: Ghrelin levels in adolescent idiopathic scoliosis. In Scoliosis Research Society $47^{\text {rd }}$ Annual Meeting and Course, Chicago, Illinois, USA, September 5-8th. 2012:110-111.

85. Khaymina T, Avaliani T, Dudin M, Pinchuk D: Neurohumoral regulation in children with idiopathic scoliosis. Stud Health Technol Inform 2012, 176:168-173.

86. Hung WWY, Qin L, Cheung CSK, Lam TP, Ng BKW, Tse YK, Go X, Lee KM, Cheng JCY: Osteopenia: a new prognostic factor of curve progression in adolescent idiopathic scoliosis. J Bone Joint Surg Am 2005, 87-A:27092716.

87. Szalay EA, Bosch P, Schwend RM, Buggie B, Tandberg D, Sherman F: Adolescents with idiopathic scoliosis are not osteoporotic. Spine 2008, 33(7):802-806.

88. Park WW, Suh KT, Kim Jl, Kim SJ, Lee JS: Decreased osteogenic differentiation of mesenchymal stem cells and reduced bone mineral density in patients with adolescent idiopathic scoliosis. Eur Spine J 2009, 18(12):1920-1926.

89. Sun GQ, Lam TP, Bobby NG, Yim PY, Lee KM, Qiu Y, Cheng JCY: Abnormal bone matrix mineralization in patients with adolescent idiopathic scoliosis. Stud Health Technol Inform 2012, 176:458.

90. Yu WS, Chan KY, Yu FWP, Yeung HY, Lee KM, Ng KW, Lok KW, Qiu Y, Lam TP, Cheng JCY: Bone quality in adolescent idiopathic scoliosis girls a case control study. Stud Health Technol Inform 2012, 176:471.

91. Yu WS, Chan KY, Yu FWP, Lee KM, Ng BKW, Liu KL, Lam TP, Cheng JC, Zhu Z, Tam EMS: Abnormal bone quality in osteopenic adolescent idiopathic scoliosis girls - a case control study. In Scoliosis Research Society $47^{r d}$ Annual Meeting and Course, Chicago, Illinois, USA, September 5-8th. 2012:127.

92. Goldberg CJ, Dowling FE, Fogarty EE, Moore DP: Adolescent idiopathic scoliosis as developmental instability. Genetica 1995, 96(3):247-255.

93. Goldberg CJ, Fogarty EE, Moore DP, Dowling FE: Scoliosis and developmental theory: adolescent idiopathic scoliosis. Spine 1997, 22(19): 2228-2237.

94. Burwell RG, Grevitt MP, Randell TL, Dangerfield PH, Ranjit RK, Cole AA, Pratt RK, Webb JK, Moulton A, Anderson SI: Abnormal bilateral skeletal asymmetries and their putative genetic and epigenetic origins in enantiomorphic growth plates of girls with adolescent idiopathic scoliosis (AIS)(abstract). Clin Anat 2012, 25(2):267.

95. Burwell RG, Aujla RK, Randell TL, Dangerfield PH, Moulton A, Anderson SI: Regional skeletal sizes of healthy girls relative to size attained at 10 years as the comparator: percentage size trajectories reveal effects of differential growth consistent with intrinsic growth-plate programs involving time-tally patterning, genetically- and epigeneticallydetermined (abstract). Clin Anat 2012, 25(2):268.

96. Grivas TB, Burwell RG, Mihas C, Vasiliadis ES, Triandaffylopoulos G, Kaspiris A: Relatively lower body mass index is associated with an excess of severe 
truncal asymmetry in healthy adolescents. Do body fat, leptin, hypothalamus and sympathetic nervous system influence truncal growth asymmetry? Scoliosis 2009, 4(1):13. doi:10,1186/1748-7161-4-13.

97. Burwell RG, Cole AA, Cook TA, Grivas TB, Kiel AW, Moulton A, Thirlwall AS, Upadhyay SS, Webb JK, Wemyss-Holden SA, et al: Pathogenesis of idiopathic scoliosis. The Nottingham concept. Acta Orthop Belg 1992, 58(Suppl 1):33-58.

98. de Sèze M, Cugy E: Pathogenesis of idiopathic scoliosis: A review. Ann Phys Rehabil Med 2012. [Epub ahead of print] (French).

99. de Mauroy JC, Ginoux JM: Is AIS under 20-30 degrees a chaotic dynamical system? Stud Health Technol Inform 2012, 176:473.

100. Burwell RG: Aetiology of idiopathic scoliosis: current concepts. Pediatr Rehabil 2003, 6(3-4):137-70.

101. Sanders JO, Browne RH, McConnell SJ, Margraf SA, Cooney TE, Finegold DN: Maturity assessment and curve progression in girls with idiopathic scoliosis. J Bone Joint Surg Am 2007, 89(1):64-73.

102. Xiong B, Sevastik B, Sevastik J, Hedlund R: Early three dimensional radiographic changes in scoliosis. In International Symposium on 3-D Scoliotic Deformities joined with the VIlth International Symposium on Spinal Deformity and Surface Topography. de l'École Polytechnique de Montrēalth edition. Edited by Dansereau J. Stuttgart, Germany: Gustav Fischer Verlag; 1992:498-504.

103. Liu Z, Zhu Z, Guo J, Mao S, Wang W, Qian B, Zhu F, Chu W, Cheng JC, Qiu $Y$ : Analysis of body growth parameters in girls with adolescent idiopathic scoliosis: single thoracic idiopathic scoliosis versus single lumbar idiopathic scoliosis. Stud Health Technol Inform 2012, 176:195-201.

104. Yim APY Yeung HY, Wang WJ, Hung WWY, Qin L, Lee KM, Lam TP, Qiu Y, Cheng $J C Y$ : Abnormal skeletal growth patterns in adolescent idiopathic scoliosis-a longitudinal study till skeletal maturity. Stud Health Technol Inform 2012, 176:474. and Spine (Phila Pa 1976). 2012 Aug 15;37(18):E1148-54.

105. Chazono M, Soshi S, Kida Y, Hashimoto K, Inoue T, Nakamura Y, Shinohara A, Marumo K, Kono K, Suzuki N: Height velocity curves in female patients with idiopathic scoliosis. Stud Health Technol Inform 2012, 176:202-5.

106. Burwell RG, James NJ, Johnson F, Webb JK, Wilson YG: Standardised trunk asymmetry scores; a study of back contour in healthy school children. J Bone Joint Surg Br 1983, 65(4):452-63.

107. Nissinen M, Heliövaara M, Seitsamo J, Poussa M: Trunk asymmetry, posture, growth, and risk of scoliosis, A three-year follow-up of Finnish prepubertal school children. Spine 1993, 18(1):8-13.

108. Janssen MM, Kouwenhoven JW, Schlösser TP, Viergever MA, Bartels LW, Castelein RM, Vincken KL: Analysis of preexistent vertebral rotation in the normal infantile, juvenile, and adolescent spine. Spine (Phila Pa 1976). 2011, 36(7):E486-91.

109. Sarnadskiy VN: The structure of postural disorders and spinal deformities in age and gender according to computer optical topography. Stud Health Technol Inform 2012, 176:77-82.

110. Sarnadskiy VN: Classification of postural disorders and spinal deformities in the three dimensions according to computer optical topography. Stud Health Technol Inform 2012, 176:159-63.

111. Pecherskiy V, Lihacheva L, Chicherin A, Dudin M, Pinchuk D: The evolution of state of vertebral column in three planes. Stud Health Technol Inform 2012, 176:164-7.

112. Kluszczynski M, Czernicki J: Analysis of changes in selected body characteristics in many years of observation of children and adolescents with faulty body posture. Stud Health Technol Inform 2012, 176:465.

113. Stolinski L, Kotwicki T: Trunk asymmetry in one thousand school children aged 7-10 years. Stud Health Technol Inform 2012, 176:259-63.

114. Stolinski L, Kotwicki T, Czaprowski D, Chowanska J, Suzuki N: Analysis of the Anterior Trunk Symmetry Index (ATSI), Preliminary report. Stud Health Technol Inform 2012, 176:242-6.

115. Burwell RG, Aujla RK, Grevitt MP, Randell TL, Dangerfield PH, Cole AA, Kirby AS, Polak FJ, Pratt RK, Webb JK, Moulton A: Upper arm length model suggest transient bilateral asymmetry is associated with right thoracic adolescent idiopathic scoliosis (RT-AIS) with implications for pathogenesis and estimation of linear growth. Stud Health Technol Inform 2012, 176:188-94.

116. D'Amico M, Roncoletta P, Di Felice F, Porto D, Bellomo R, Saggini R: Leg length discrepancy in scoliotic patients. Stud Health Technol Inform 2012, 176:146-50.

117. Shi L, Wang D, Chu WC, Burwell RG, Freeman BJ, Heng PA, Cheng JC: Volume-based morphometry of brain MR images in adolescent idiopathic scoliosis and healthy control subjects. AJNR Am J Neuroradiol 2009, 30(7):1302-7.

118. Bardin J: Neuroscience: Making connections. Nature 2012, 483(7390):394-6. doi:10.1038/483394a

119. Wang D, Shi L, Chu WC, Burwell RG, Cheng JC, Ahuja AT: Abnormal cerebral cortical thinning pattern in adolescent girls with idiopathic scoliosis. Neuroimage 2012, 59(2):935-42.

120. Benoist M: The Michel Benoist and Robert Mulholland yearly European Spine Journal review: a survey of the "medical" articles in the European Spine Journal, 2011. Eur Spine J 2012, 21(2):185-94.

121. Freeman BJ: Reviewer's comment concerning "Abnormal activation of the motor cortical network in idiopathic scoliosis demonstrated by functional MRI". Eur Spine J 2011, 20(7):1079-80. doi:10.1007/s00586-0111776-8. by J. Domenech et al.

122. Huber J, Rogala P: Etiopathogenesis of the adolescent idiopathic scoliosis basing on neuroimaging and neurophysiological examinations with the special emphazing of motor evoked potentials (MEP). Stud Health Technol Inform 2012, 176:446.

123. Pinchuk D, Dudin M, Bekshayev S, Pinchuk O: Peculiarities of brain functioning in children with adolescence idiopathic scoliosis (AIS) according to EEG studies. Stud Health Technol Inform 2012, 176:87-90.

124. Chu WC, Shi L, Wang D, Cheng JCY: Statistical difference in cerebral cortical thickness in patients with adolescent idiopathic scoliosis and normal controls using computational techniques - the updated data. Stud Health Technol Inform 2012, 176:481.

125. Wiernicka M, Lochynski D, Kotwicki T, Michalowski L, Kaminska E, Lewandowski J, Hurnik E: Static and dynamic postural control in girls with idiopathic scoliosis. Stud Health Technol Inform 2012, 176:460.

126. Syngayevskaya I, Bumakova S, Pinchuk D, Dudin M: Integrated assessment of back muscles bioelectrical activity and $\mathrm{H}$-reflex research in AIS. Stud Health Technol Inform 2012, 176:83-6.

127. Waldrop MM: Computer modelling: Brain in a box. Nature 2012, 482(7386): 456-8. doi:10.1038/482456a.

128. Koch C, Reid RC: Neuroscience: Observatories of the mind. Nature 2012 , 483(7390):397-8. doi:10.1038/483397a

129. Barabasi AL, Gulbahce N, Loscalzo J: Network medicine: a network-based approach to human disease. Nat Rev Genet 2011, 12(1):56-68.

130. Shi L, Wang D, Driscoll M, Villemure I, Chu WC, Cheng JC, Aubin CE: Biomechanical analysis and modeling of different vertebral growth patterns in adolescent idiopathic scoliosis and healthy subjects. Scoliosis 2011, 6:11

131. Ledford H: Life-changing experiments: The biological Higgs. Nature 2012, 483(7391):528-30. doi:10.1038/483528a.

132. Kirkwood TB, Melov S: On the programmed/non-programmed nature of ageing within the life history. Curr Biol 2011, 21(18):R701-7.

133. Tang NL, Yeung HY, Hung WW, Liao CD, Lam TP, Yeung HM, Lee KM, Ng BK, Cheng JC: Genetic epidemiology and heritability of AIS: A study of 415 Chinese female patients. J Orthop Res 2012. doi:10.1002/jor.22090

134. Sharma S, Gao X, Londono D, Devroy SE, Mauldin KN, Frankel JT, Brandon JM, Zhang D, Li QZ, Dobbs MB, Gurnett CA, Grant SF, Hakonarson H, Dormans JP, Herring JA, Gordon D, Wise CA: Genome-wide association studies of adolescent idiopathic scoliosis suggest candidate susceptibility genes. Hum Mol Genet 2011, 20(7):1456-62.

135. Wise C, Herring JA, Guo X, Zhong D, Sharma S: Idiopathic scoliosis mutations in VANGL1 on axial development gene. In Scoliosis Research Society $47^{\text {rd }}$ Annual Meeting and Course, Chicago, Illinois, USA, September 58th. 2012:90-1.

136. Takahashi Y, Matsumoto M, Kono K, Kawakani M, Ito M, Uno K, Minani S, Yanagida H, Taneichi H, Watanabe K, Tsuji T, Sudo H, Suzuki T, Toyama Y, Ikegawa S: A genome wide association study identified a new susceptibility locus for adolescent idiopathic soliosis. In Scoliosis Research Society $47^{\text {rd }}$ Annual Meeting and Course, Chicago, Illinois, USA, September 58th. 2012:90.

137. Gorman KF, Julien C, Yuan Q, Franco A, Wang DS, Bouhanik S, Larouche G, Lacroix $G$, Moreau $A$ : The identification of unique gene expression, profiles associated with cellular and biochemical endophenotypes of idiopathic scoliosis. Stud Health Technol Inform 2012, 176:450.

138. Janusz P, Kotwicki T, Kotwicka M, Andrusiewicz M: Association of CHD7 polymorphism with susceptibility to and severity of idiopathic scoliosis in central European population: preliminary study. Stud Health Technol Inform 2012, 176:448 
139. Zhou S, Zhu Z, Qiu X, Wu W, Wang W, Liu Z, Lv F, Qiu Y: Association study of IL-17RC, CHL1, DSCAM and CNTNAP2 genes polymorphisms with adolescent idiopathic scoliosis susceptibility in a Chinese Han population. Stud Health Technol Inform 2012, 176:47-51.

140. Harasymczuk P, Janusz P, Kotwick IT: Genetic association studies in idiopathic scoliosis - who was really tested? Stud Health Technol Inform 2012, 176:451.

141. Moldovan F, Patten SA, Fendri K, Girard S, Zaouter C, Edery P: Exome sequencing identifies novel candidate nutations in idiopathic scoliosis. Stud Health Technol Inform 2012, 176:453.

142. Ward K, Ogilvie JW, Singleton MV, Chettier R, Engler G, Nelson LM: Validation of DNA-based prognostic testing to predict spinal curve progression in adolescent idiopathic scoliosis. Spine (Phila Pa 1976). 2010, 35(25):E1455-64

143. Ogilvie JW: Update on prognostic genetic testing in adolescent idiopathic scoliosis (AIS). J Pediatr Orthop 2011, 31(1 Suppl):S46-8.

144. Cahill KS, Wang MY: DNA-based prediction of scoliosis curve progression. World Neurosurg 2011, 76(5):371.

145. Carlson B: Scoliscore AIS prognostic test personalizes treatment for children with spinal curve. Biotechnol Healthc 2011, 8(2):30-31.

146. Ward K, Nelson LM, Chettier R, Ogilvie JW: The clinical value of an intermediate risk score with AIS prognostic testing. In Scoliosis Research Society $47^{\text {td }}$ Annual Meeting and Course, Chicago, Illinois, USA, September 5-8th. 2012:98

147. Nelson LM, Ogilvie JW, Ward K: AIS Prognostic Test (AIS-PT) testing of patients with advanced Cobb angles provides further validation of the Test algorithm. In Scoliosis Research Society $47^{\text {rd }}$ Annual Meeting and Course, Chicago, Illinois, USA, September 5-8th. 2012:154-5.

148. Ward K: Comparing apples and oranges: pathogenesis of adolescent idiopathic scoliosis varies by patient ancestry. In Scoliosis Research Society $47^{\text {rd }}$ Annual Meeting and Course, Chicago, Illinois, USA, September 5-8th. 2012:90.

149. Ogilvie JW, Chettier R, Nelson LM, Ward K: DNA-based prognostic test scores are higher in patients who fail orthotic treatment for adolescent idiopathic scoliosis. In Scoliosis Research Society $47^{\text {rd }}$ Annual Meeting and Course, Chicago, Illinois, USA, September 5-8th. 2012:159.

150. Nault M-L, Mac-Thiong J-M, Roy-Beaudry M, Turgeon I, Labelle H, de Guise J, Parent S: The use of 3D spinal parameters to differentiate between progressive and non-progressive AIS curves at he first visit. In Scoliosis Research Society $47^{\text {rd }}$ Annual Meeting and Course, Chicago, Illinois, USA, September 5-8th. 2012:62.

151. Butcher LM, Beck S: Future impact of integrated high-throughput methylome analyses on human health and disease. J Genet Genomics 2008, 35(7):391-401.

152. Bjornsson HT, Fallin MD, Feinberg AP: An integrated epigenetic and genetic approach to common human disease. Trends Genet 2004, 20(8): 350-8.

153. Nelissen EC, van Montfoort AP, Dumoulin JC, Evers JL: Epigenetics and the placenta. Hum Reprod Update 2011, 17(3):397-417.

154. Silahtaroglu A, Stenvang J: MicroRNAs, epigenetics and disease. Essays Biochem 2010, 48(1):165-85.

155. Talens RP, Boomsma DI, Tobi EW, Kremer D, Jukema JW, Willemsen G, Putter H, Slagboom PE, Heijmans BT: Variation, patterns, and temporal stability of DNA methylation: considerations for epigenetic epidemiology. FASEB J 2010, 24(9):3135-44.

156. Grivas TB, Mihas C, Mazioti C, Zisis N, Sakellaropoulou S, Akriotis A, Burwell RG: Maternal age at birth: does it dictate the epigenotypic expression of the trunkal asymmetry of a child? Stud Health Technol Inform 2012, 176:36-42.

157. Burwell RG, Dangerfield PH, Vernon CL: Anthropometry and scoliosis. In Scoliosis, Proceedings of a Fifth Symposium, Edited by Zorab PA. London: Academic; 1977:123-163.

158. Burwell RG, Dangerfield PH, James NJ, Johnson F, Webb JK, Wilson YG: Anthropometric studies of normal and scoliotic children: axial and appendicular skeletal asymmetry, sexual dimorphisms and age-related changes. In Pathogenesis of idiopathic scoliosis. Proceedings of an international conference. Edited by Jacobs RR. Chicago: Scoliosis Research Society; 1984:27-44

159. McMaster M, Lee AJ, Burwell RG: Physical activities of patients with adolescent idiopathic scoliosis (AIS) compared with a control group: implications for etiology and possible prevention. In International
Research Society of Spinal Deformities Symposium. Edited by Sawatzky BJ. Vancouver: University of British Columbia; 2004:68-71.

160. McMaster M, Lee AJ, Burwell RG: Indoor heated swimming pools: vulnerability of some infants to develop spinal asymmetries years later. Stud Health Technol Inform 2006, 123:151-155.

161. McMaster ME: Heated indoor swimming pools, infants, and the pathogenesis of adolescent idiopathic scoliosis: a neurogenic hypothesis. Environ Health 2011, 10:86.

162. Herring JA: Scoliosis: Chapter 11. In Tachdjian's Pediatric Orthopaedics, Volume 1. Third Editionth edition. Philadelphia: WB Saunders; 2002:215

163. Burwell RG, Grevitt MP, Randell TL, Dangerfield PH, Cole AA, Pratt RK, Webb JK, Moulton A, Anderson SI, : Several phenotypic features of girls with adolescent idiopathic scoliosis (AIS) are explained by postulating hypothalamic alterations in two successive normal life-history phase transitions (abstract). Clin Anat 2012, 24(6):800.

164. Matusik E, Durmała J, Matusik P, Malecka-Tendera E: Nutritional status of children and adolescents with idiopathic scoliosis preliminary results. Stud Health Technol Inform 2012, 176:476. and in Ortop Traumatol Rehabil. 2012 14(4):351-62. doi: 10.5604/15093492.1005093.

165. Taubes G: Unravelling the obesity-cancer connection. Science 2012 , 335(6064):28-32.

166. Reardon S: A world of chronic disease. Science 2011, 333(6042):558-9.

167. Reardon S: U.N. Summit on non-communicable diseases. Meeting brings attention but little action on chronic diseases. Science 2011, 333(6049):1561.

168. Garber K: Autophagy, Explaining exercise. Science 2012, 335(6066):281.

169. Gluckman P, Hanson M: Fat fate \& disease. Oxford, UK: Oxford University Press; 2012:288.

170. Godfrey KM, Sheppard A, Gluckman PD, Lillycrop KA, Burdge GC, McLean C, Rodford J, Slater-Jefferies JL, Garratt E, Crozier SR, Emerald BS, Gale CR, Inskip HM, Cooper C, Hanson MA: Epigenetic gene promoter methylation at birth is associated with child's later adiposity. Diabetes 2011, 60(5): $1528-34$.

171. Davey RC, Cochrane T, Dangerfield PH, Chockalingam N, Dorgan JC: Anthropometry and body composition in females with adolescent idiopathic scoliosis, International Research Society of Spinal Deformities Symposium. Vancouver: Edited by Bonita J Sawatzky; 2004:323-6.

172. Barrios C, Cortés S, Pérez-Encinas C, Escrivá MD, Benet I, Burgos J, Hevia E, Pizá G, Domenech P: Anthropometry and body composition profile of girls with nonsurgically treated adolescent idiopathic scoliosis. Spine (Phila Pa 1976). 2011, 36(18):1470-7.

173. Iwaniec UT, Boghossian S, Lapke PD, Turner RT, Kalra SP: Central leptin gene therapy corrects skeletal abnormalities in leptin-deficient ob/ob mice. Peptides 2007, 28(5):1012-9.

174. Iwaniec UT, Wong CP, Lindenmaier LB, Philbrick KA, Olson DA, Turner RT: Reduced peripheral leptin signaling drastically reduces bone formation In Proceedings of ASBMR Annual Meeting, September 16-20. San Diego, California, USA; 2011.

175. Burwell RG, Aujla RK, Grevitt MP, Dangerfield PH, Cole AA, Kirby AS, Polak FJ, Pratt RK, Moulton A, Webb JK, Anderson SI: Leptin, asymmetric bone growth, pathogenesis of adolescent idiopathic scoliosis (AIS), and hormesis: Lower spine scoliosis (Abstract). Clin Anat 2009, 22(3):411.

176. Burwell RG, Aujla RK, Grevitt MP, Dangerfield PH, Moulton A, Randell TL, Anderson SI: Pathogenesis of adolescent idiopathic scoliosis (AIS) in girls a double neuro-osseous theory involving disharmony between two nervous systems, somatic and autonomic expressed in the spine and trunk: possible dependency on sympathetic nervous system and hormones with implications for medical therapy. Stud Health Technol Inform 2010, 158:212.

177. Zuo T, Tycko B, Liu TM, Lin JJ, Huang TH: Methods in DNA methylation profiling. Epigenomics 2009, 1(2):331-45

178. Lin SY, Lee CN, Hung CC, Tsai WY, Lin SP, Li NC, Hsieh WS, Tung YC, Niu DM, Hsu WM, Chen LY, Fang MY, Tu MP, Kuo PW, Lin CY, Su YN, Ho HN: Epigenetic profiling of the $\mathrm{H} 19$ differentially methylated region and comprehensive whole genome array-based analysis in Silver-Russell syndrome. Am J Med Genet A 2010, 152A(10):2521-8.

179. Bruce S, Hannula-Jouppi K, Peltonen J, Kere J, Lipsanen-Nyman M: Clinically distinct epigenetic subgroups in Silver-Russell syndrome: the degree of $\mathrm{H} 19$ hypomethylation associates with pheotype severity and genital and skeletal anomalies. J Clin Endocrinol Metab 2009, 94(2):579-87.

180. Adams J: Collaborations: The rise of research networks. Nature 2012, 490(7420):335-6. doi:10.1038/490335a. 
181. Abbott A, Schiermeier Q: Research prize boost for Europe. Nature 2013, 493(7434):585-6. doi:10.1038/493585a.

182. Markoff J: Obama seeking to boost study of human brain. New York: The New York Times; 2013:A1.

183. Underwood E, Kaiser J: Brain project draws Presidential interest. Scienceinsider; 2013.

doi:10.1186/1748-7161-8-4

Cite this article as: Burwell et al:: Whither the etiopathogenesis (and scoliogeny) of adolescent idiopathic scoliosis? Incorporating

presentations on scoliogeny at the 2012 IRSSD and SRS meetings. Scoliosis 2013 8:4.

\section{Submit your next manuscript to BioMed Central and take full advantage of:}

- Convenient online submission

- Thorough peer review

- No space constraints or color figure charges

- Immediate publication on acceptance

- Inclusion in PubMed, CAS, Scopus and Google Scholar

- Research which is freely available for redistribution 